\title{
Cattle use of foothills rangeland near dehydrated molasses supplement
}

\author{
DEREK W. BAILEY, G. ROBERT WELLING, AND ERIC T. MILLER
}

Authors are assistant professor and former research technicians, Northern Agricultural Research Center, Montana State University, Star Route 36 Box 43 ,

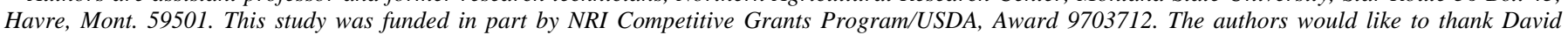
Cameron and the staff of the Dana Ranch and Steve Roth and the staff of the IX Ranch for their cooperation in this study.

\begin{abstract}
Strategic supplement placement has been shown to be an effective tool to lure cattle to underutilized rangeland. The goal of this study was to determine where cattle grazed when supplement was placed in foothills rangeland. The study was conducted in 4 pastures in northern Montana that were dominated by cool-season grasses. For 2-week periods beginning in October 1998 and ending in January 1999, dehydrated molasses blocks (30\% CP) were placed in locations within 3 pastures that were steeper and further from water. Forage utilization was measured at the time of supplement placement and again at removal. Increases in forage utilization during each period $(14 \%)$ were similar $(P>0.1)$ at distances of 30 to $600 \mathrm{~m}$ from supplement, and increases were additive across periods. Forage utilization was evaluated in a fourth pasture during August and September 1999 at distances of 50 to $3,000 \mathrm{~m}$ from the supplement. Forage use declined $(P<$ 0.01) at further distances from supplement, and forage use at distances less than 600 to $800 \mathrm{~m}$ from supplement was greater than the average of all measurements collected throughout the pasture. During the autumn and early winter at the 2 pastures located near Havre, Mont., $53 \%$ of the cows were observed within 600 $\mathrm{m}$ of supplement and $47 \%$ were observed at greater distances from supplement. Eighty-one of the 159 cows grazing the 2 pastures near Havre (245 and 330 ha) were fitted with Global Positioning System (GPS) tracking collars. The collared cows spent $37 \%$ of their time within $600 \mathrm{~m}$ of supplement. Uniformity of cattle grazing can be enhanced by the placement of dehydrated molasses supplement in rugged topography, and the area influenced can include distances up to $600 \mathrm{~m}$ from supplement.
\end{abstract}

Key Words: distribution, grazing, behavior, utilization

Uneven livestock grazing distribution is often associated with many resource concerns on rangelands. Increasing the uniformity of grazing and preventing concentrated heavy grazing in localized areas is one of the principles of rangeland management (Bell 1973). In addition to management practices such as developing water, salting, fencing and herding (Cook 1966, Bailey and Rittenhouse 1989), strategic placement of supplement has been used to modify livestock grazing distribution (Martin and Ward 1973, McDougald et al. 1989). Most commercially available supplements fed to cattle are palatable and potentially could be used to lure aimals to underutilized rangeland. Dehydrated molasses

Manuscript accepted 10 Oct. 2000.

\section{Resumen}

La colocación estratégica del suplemento ha mostrado ser una herramienta efectiva para atraer el ganado hacia áreas subutilizadas del pastizal. La meta de este estudio fue determinar donde apacienta el ganado cuando el suplemento se coloca en los pastizales de pie de montaña. El estudio se condujo en cuatro potreros del norte de Montana dominados por zacates de estación fría. Por periodos de 2 semanas, iniciando en Octubre de 1998 y terminando en Enero de 1999, se colocaron bloques de melaza deshidratada ( $30 \%$ PC) en lugares dentro de los 3 potreros que eran áreas con pendiente pronunciada y lejos del agua. La utilización del forraje se midió al momento de colocar el suplemento y nuevamente al remover los bloques. Los incrementos en la utilización del forraje durante cada periodo fueron similares $(14 \%)(P>0.1)$ en las distancias de 30 y $600 \mathrm{~m}$ del suplemento y el aumento fue aditivo a través de los periodos. La utilización del forraje se evaluó en un cuarto potrero durante Agosto y Septiembre de 1999 a distancias de 50 y 3,000 m del suplemento. El uso del forraje disminuyo $(P<0.01)$ conforme la distancia del suplemento fue mayor y el uso del forraje a distancias menores de 600 a $800 \mathrm{~m}$ del suplemento fue mayor que el promedio de todas las medidas colectadas a través del potrero. Durante el otoño e inicios de invierno en los 2 potreros localizados cerca de Havre, Mont., el 53\% de las vacas se observaron dentro de una distancia de $600 \mathrm{~m}$ del suplemento y $47 \%$ restante se observó a distancias mayores. A 81 de las 159 vacas que apacentaban en los 2 potreros cerca de Havre ( 245 y 330 ha) se les colocó un collar de restero de un Sistema de Posicionamiento Global (GPS). Las vacas con collar gastaron el 37\% de su tiempo dentro de $600 \mathrm{~m}$ del suplemento. En áreas de topografía escabrosa la uniformidad del apacentamiento del ganado se puede mejorar con la colocación de suplemento de melaza deshidratada y el área influenciada puede incluir distancia hasta de $600 \mathrm{~m}$ del suplemento.

supplements are available in containers (blocks weighing up to $113 \mathrm{~kg}$ ) that can be transported to rugged rangeland and then self fed. Most containers last up to 2 weeks before they are emptied and should be replaced to maintain intake. Bailey and Welling (1999) showed that cattle spent more time and grazed more forage in pasture areas where dehydrated molasses supplement was provided than in similar control areas where no supplement was provided. Although it was more effective in moderate terrain (10-20\% slopes), strategic supplement placement noticeably changed livestock grazing patterns in steeper terrain (15-30\% slopes) at greater distances from water. Ongoing work in 
California (Mel George, personal communication) also suggests that dehydrated molasses supplement can modify cattle grazing patterns.

Although previous and ongoing research has demonstrated that strategic supplement placement can be effective, several aspects of this practice are not known. Protocols for its practical use are not in place and should be developed. Experimental procedures used in the past (Bailey and Welling 1999) would not be practical for range livestock producers. The effect of strategic supplement placement on livestock grazing distribution should be evaluated throughout the year. Bailey and Welling (1999) studied the effects of dehydrated molasses supplement on grazing distribution during the autumn and winter (October to January) when the forage was mature and dormant, but this practice also may be effective during late summer (August and September). To conduct economic evaluations of this practice, the area impacted by supplement placement must be estimated. Bailey and Welling (1999) found that forage use was similar at distances of 20 to $200 \mathrm{~m}$ from supplement. To determine the area impacted by a single placement, forage use must be evaluated at distances further from supplement.

Objectives of this study were to: 1 ) develop and evaluate a practical approach for strategic placement of dehydrated molasses supplements during late summer, autumn and early winter, 2) estimate the distance that cattle grazing distribution was affected by supplement placement. In this study, effect of supplement was initially evaluated at distances of 30 to $600 \mathrm{~m}$ from supplement, and distances of 30 to 3,000 m were examined later.

\section{Methods}

\section{Study sites}

The study was conducted at 3 locations in northern Montana: Thackeray Ranch, Dana Ranch, and IX Ranch. Forage measurements were collected at all locations, but animal behavior observations were collected only at the Thackeray Ranch, near Havre, Mont.

Thackeray Ranch. The Thackeray Ranch is located in the Bear's Paw Mountains $30 \mathrm{~km}$ south of Havre, Mont. Two pastures were used at this study site, Rakes Draw and Anderson. The Rakes Draw pasture $\left(48^{\circ} 21^{\prime} 29^{\prime \prime} \mathrm{N} 109^{\circ} 34^{\prime} 31^{\prime \prime} \mathrm{W}\right)$ is approximately 245 ha with elevations varying from 1,150 to $1,320 \mathrm{~m}$. The
Anderson pasture $\left(48^{\circ} 22^{\prime} 44^{\prime \prime} \mathrm{N} 109^{\circ}\right.$ $\left.37^{\prime} 21^{\prime \prime} \mathrm{W}\right)$ is approximately 330 ha bisected with a perennial stream (Bull Hook Creek). Topographic relief varies from 1,055 to $1,222 \mathrm{~m}$. Both pastures were dominated by Kentucky bluegrass (Poa pratensis L.), bluebunch wheatgrass (Pseudoregnaria spicata [Pursh] A Love), rough fescue (Festuca scabrella Torr.), and Idaho fescue (Festuca idahoensis Elmer). Soils were primarily shallow clays and gravelly loams.

Dana Ranch. The Dana Ranch is located $35 \mathrm{~km}$ south of Cascade, Mont. in rugged foothill rangeland near the Big Belt Mountains. Two study areas were established within a 4,900 ha pasture. Study areas were approximately 325 ha in size and located about $2.5 \mathrm{~km}$ from each other. One area was identified as Coyote $\left(47^{\circ}\right.$ $01^{\prime} 38^{\prime \prime} \mathrm{N} 111^{\circ} 29^{\prime} 35^{\prime \prime} \mathrm{W}$ ) and the other was identified as Pine Coulee $\left(47^{\circ} 00^{\prime} 30^{\prime \prime} \mathrm{N}\right.$ $\left.111^{\circ} 30^{\prime} 00^{\prime \prime} \mathrm{W}\right)$. The 2 study areas were evaluated simultaneously. Relief in the pasture varied from 1,220 to $1,680 \mathrm{~m}$, but elevations in the study areas varied from 1,490 to $1,680 \mathrm{~m}$. Study areas were dominated by timothy (Phleum pratense L.), rough fescue, and Kentucky bluegrass. Soils in the study area were primarily deep to shallow loams.

IX Ranch. The IX Ranch is located in the Bear's Paws Mountains, approximately $30 \mathrm{~km}$ east of Big Sandy, Mont. (48 $\left.04^{\prime} 55^{\prime \prime} \mathrm{N} 109^{\circ} 51^{\prime} 30^{\prime \prime} \mathrm{W}\right)$. The study was conducted in a pasture (approximately 2,020 ha) containing gentle and rugged topography. Vegetation on gentler slopes ( 5 to $15 \%$ slopes) was dominated by Kentucky bluegrass with significant quantities of bluebunch wheatgrass, western wheatgrass (Pascopyrum smithii Rydb.(Love)), prairie junegrass (Koeleria macrantha (Ledeb.) Schult.), and blue grama (Bouteloua gracilis (H. B. K.) Lag. ex Griffiths). On

Table 1. Nutrient concentration and ingredients of the dehydrated molasses supplement used in the study.

\begin{tabular}{lc}
\hline \hline Nutrient & Level \\
\hline & $(\%)$ \\
Crude protein & 30.0 \\
$\quad$ Not more than $12 \%$ equivalent & \\
crude protein from non-protein & \\
$\quad$ nitrogen & \\
Crude fat & 4.0 \\
Crude fiber & 2.5 \\
\hline
\end{tabular}

Ingredients: Molasses products, animal fat (preserved with ethoxquin), plant protein products, animal protein products, processed grain by-products, urea, monocalcium phosphate, dicalcium phosphate, calcium carbonate, mag nesium oxide, sulfur, vitamin A acetate, D-activated animal sterol, vitamin E supplement, zinc sulfate, manganous oxide, ferrous sulfate, copper carbonate, calcium iodate, sodium selenite. steeper slopes, vegetation was dominated by rough fescue and bluebunch wheatgrass. Elevation in the pasture varied from 1,100 to $1,460 \mathrm{~m}$. Soils were primarily shallow to deep loams with some areas of clays.

\section{Supplement placement}

Thackeray Ranch. Dehydrated molasses supplement $(30 \% \mathrm{CP})$ was placed at a rate of 1 barrel (113 kg-block) per 20 cows (Table 1). In each pasture, 8 barrels were placed in pairs (2 barrels/site) about $30 \mathrm{~m}$ apart, similar to the Bailey and Welling (1999) study. Salt blocks (23 kg, >99 to $99.9 \% \mathrm{NaCl}$ ) were placed at 2 of the 4 supplement sites. The 4 supplement sites (site $=1$ pair of barrels) were arranged in a rectangular pattern about 200 to $250 \mathrm{~m}$ between sites (Fig. 1). Supplement was not placed near water nor within extreme terrain (>40\% slopes). In the Rakes Draw pasture, supplement was placed in areas classified as difficult using the criteria of Bailey and Welling (1999). Terrain classified as difficult was the usable area $(<40 \%$ slopes) that contained the steeper slopes or was further from water than the moderate or easy terrain. Easy terrain was the gentle terrain near water. In the Anderson pasture, supplement was placed only in areas classified as difficult in the Bailey and Welling (1999) study.

Every 2 weeks, previously used supplement barrels were removed and full supplement barrels were placed in an adjacent area at least $250 \mathrm{~m}$ from the previous location (Fig. 1). Supplement was provided to cattle in the Rakes Draw pasture for three, 2-week periods (periods 1 to 3, 9 October 1998 to 26 November 1998) and in the Anderson pasture for four, 2-week periods (periods 4 to 7, 26 November 1998 to 19 January 1999).

The supplement placement pattern used in this study was based on previous experience (Bailey and Welling 1999). The purpose of placing new supplement in nearby underutilized areas was to facilitate cattle finding new supplement sites and to allow managers to progressively move supplement through underutilized sections of a pasture. Travel time to place supplement and remove empty barrels was reduced because new barrels were placed near empty barrels that needed to be picked up.

Dana Ranch. Ten dehydrated molasses supplement barrels (Table 1) were placed in each study area (i.e., Coyote and Pine Coulee) at the Dana Ranch (20 total). Supplement was placed in a rectangular pattern similar to that used at the Thackeray Ranch with the additional 2 

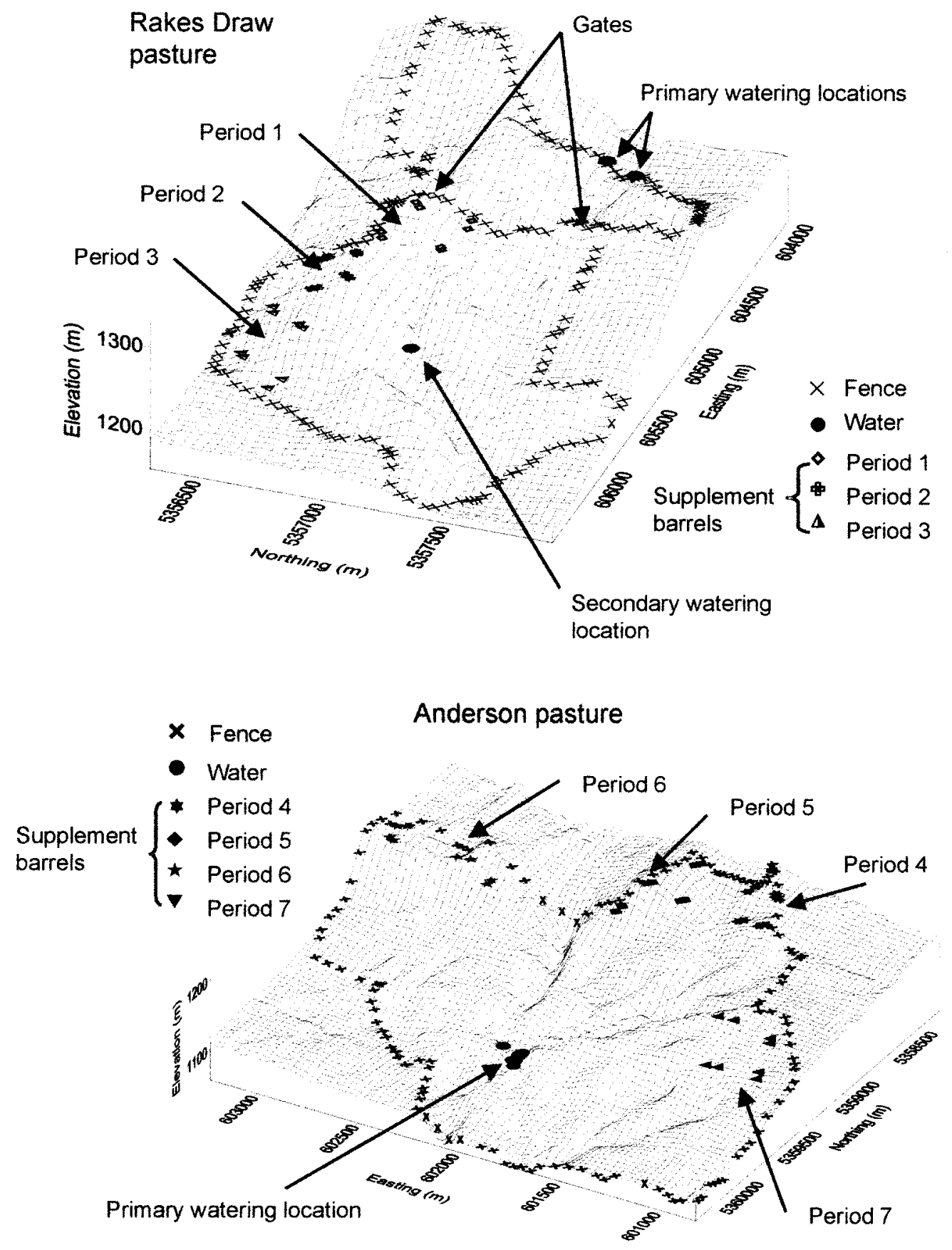

Fig. 1. Diagrams of the Anderson and Rakes Draw pastures. Fencelines are indicated by "x". Two open gates allowed cattle access to the 2 sections of the Rakes Draw pasture. Eight supplement barrels were placed during each 2-week period. In the Anderson pasture, cattle watered in Bull Hook Creek that bisects the pasture. Most cattle watered at the location marked primary watering location. In the Rakes Draw pasture cattle watered at the primary watering location. The secondary water location provided enough water for only 40 to 50 of the 159 cows in the pasture.

barrels placed in the middle of the rectangular supplement area. Salt blocks (described previously) were placed at 3 of the 5 sites (pair of barrels). New supplement barrels were placed and previously placed barrels were removed every 2 weeks. The study was conducted for three, 2 -week periods in each study area beginning 4 November
1998 and ending 15 December 1998. Supplement was placed only in terrain classified as difficult (Bailey and Welling 1999). 


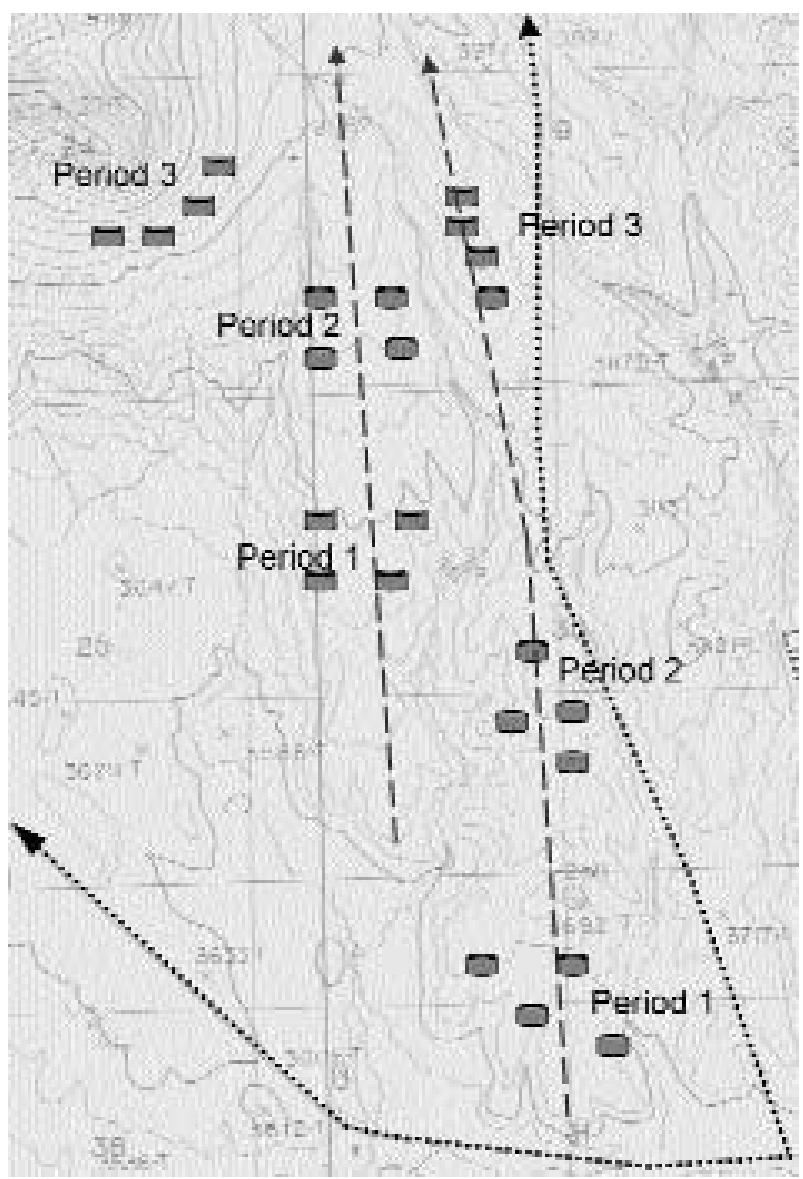

Fig. 2. Map of a portion of the pasture at the IX Ranch where the study was conducted. The map was adapted from a 7.5-minute topographic map. Contour intervals are $12 \mathrm{~m}$. The pasture fence is indicated by a dotted line ( .... ). The north-south lines where vegetative measurement transects were collected are indicated by dashed lines ( ---- ). Dark cylinders indicate the approximate locations of supplement barrel pairs. Barrels were placed in 2 general locations in each of 3 periods.

IX Ranch. The IX Ranch study was conducted after completing the studies at the Thackeray and Dana Ranches. The protocol was changed slightly to facilitate measurement of forage utilization at distances further from supplement and to fit the terrain and management goals of the ranch. At the beginning of each period (10 to 14 days), new dehydrated molasses supplement barrels (Table 1) were placed, and previously placed supplement barrels were removed. Period 1 began 12 August 1999 and ended 29 August 1999, period 2 began 30 August 1999 and ended 12 September 1999, and period 3 began 13 September 1999 and ended 23 September 1999. During each period, supplement ( 8 to 12 barrels) was placed in each of 2 general locations (Fig. 2). Eight to 12 barrels were placed in each location. Similar to the Thackeray and Dana Ranch studies, supplement barrels were placed in pairs in a rectangular pattern. Loose salt (99 to 99.9\% $\mathrm{NaCl}$ ) was placed in 2 separate locations roughly $200 \mathrm{~m}$ from water. ment would be moved along benches in a south to north direction. The benches contained similar topography and vegetation (Fig. 2). The benches were considered easy to moderate terrain based on the criteria used by Bailey and Welling (1999), but they have historically received little grazing use (Steve Roth, personal communication). During period 3, supplement was placed on steeper terrain (> $20 \%$ slopes) near the west bench.

\section{Cattle}

The protocol for this study was approved by the Institutional Animal Care and Use Committee of Montana State northern Montana rangeland cattle opera-
The study was designed so that suppleUniversity. Management was typical of tions. Two of the ranches (Dana and IX) were large commercial cow-calf operations $(>1,500 \mathrm{AU})$ that utilized extensive rangeland pastures. Cattle were treated at least annually for external parasites and may or may not have been treated for internal parasites. Treatment for internal parasites did not affect performance of rangeland beef cows in northern Montana (Bailey et al. 1997). Vaccination programs were based on recommendations from local veterinarians.

Thackeray Ranch. A total of 159 cowcalf pairs of Hereford and Tarentaise breeding were provided dehydrated molasses supplement for 2 weeks before the study (14 September 1998 to 30 September 1998) to reacquaint them with the supplement. These cows had 1 year's previous experience with dehydrated molasses supplement in the Bailey and Welling (1999) study. Mean cow weight during the study was $590 \mathrm{~kg}$. Cow age averaged 5 year and varied from 3 to 8 year. Calves were weaned on 1 October 1998 at the Thackeray Ranch, and the study began on 9 October 1998 in the Rakes Draw pasture. Cows were moved from the Rakes Draw to the Anderson pasture on 26 November 1998. Cows were moved from Anderson pasture and the study ended on 19 January 1999.

Dana Ranch. Approximately 1200 nonlactating cows with Angus and Angus x Hereford breeding were placed in the pasture on 4 November 1998. Although the study ended on 15 December 1998, cattle remained in the pasture until mid-March 1999. Cattle had been exposed to dehydrated molasses supplement for 4 consecutive years before this study, including the Bailey and Welling (1999) study in 1997.

IX Ranch. Cow-calf pairs $(\mathrm{n}=824)$ with Hereford and Red Angus breeding grazed the study pasture from 12 August 1999 to 23 September 1999. Cattle had not been exposed to dehydrated molasses supplements prior to the study. To initially train the cattle, 12 barrels of dehydrated molasses supplement were placed near water (100 to $400 \mathrm{~m}$ ) in separate pastures from 1 August 1999 to 12 August 1999.

\section{Forage measurements}

Thackeray and Dana Ranches. Forage use was measured before placement and after supplement removal at 2 randomly selected locations within the rectangular barrel pattern. Measurements also were obtained at distances of 200, 300, 400, 500 and $600 \mathrm{~m}$ from supplement (Fig. 3). The 200-, 400-, and 600-m measurements were repeated in 2 directions away from the rec- 


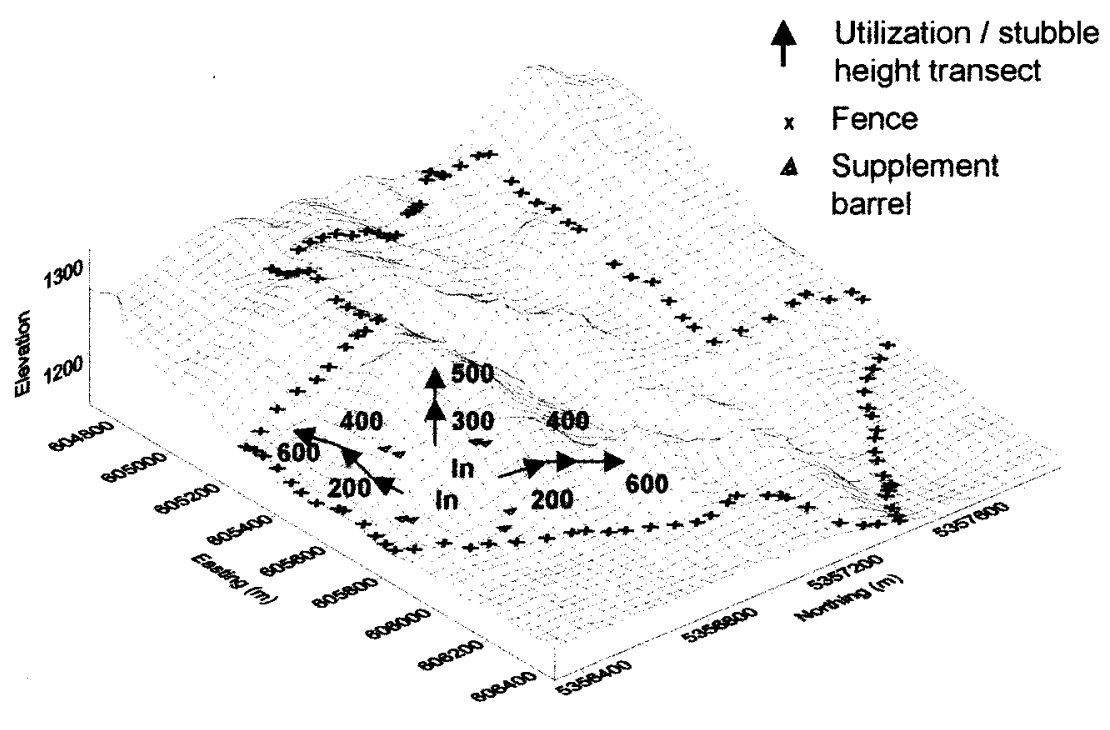

Fig. 3. Example of forage utilization and stubble height measurements in period 3 (third barrel placement) in the Rakes Draw pasture. Utilization/stubble height transects began at distances of $200,300,400,500$, and $600 \mathrm{~m}$ from supplement as indicated by the end of the arrow. In addition, 2 transects (identified as "In") were completed inside the rectangular barrel pattern.

tangular supplement placement pattern along the contour. The measurements 300 and $500 \mathrm{~m}$ from supplement were collected along a line perpendicular to the 200-, 400-, and 600-m measurements. Forage measurements at each interval consisted of measuring the stubble height of 20 grass plants along a 40-m transect $(2 \mathrm{~m}$ between plants). The beginning and end of each transect was marked with plastic surveyor flags to help ensure that measurements before and after supplement placement were collected in the same location. The slope at each transect was recorded using an inclinometer. Observers were trained to measure the intervals between transects and measure the 2-m intervals between stubble height readings using steps so that the measurements could be collected in a reasonable amount of time. Stubble heights were converted to forage utilization levels using height-weight curves (Cook and Stubbendieck 1986). Ungrazed heights were measured before grazing when supplement was first placed in the pastures. Height-weight curves were developed for major species (Kentucky bluegrass, rough fescue, and timothy) and published relationships (US Forest Service 1980) were used for other grasses.

In the Anderson pasture, deep snowdrifts prevented retrieval of supplement at the end of period 6. Additional supplement was placed in a new location (opposite side of the pasture) during period 7 (Fig.
Ryan Butte (Fig. 2). Forage use measurements were also collected in a line west of the supplement placed on the southern slope of Ryan Butte and included steeper slopes (> 20\%). In addition, forage utilization was observed at 14 randomly-selected locations throughout the entire pasture. All of these additional forage utilization measurements were collected using the protocol described above.

Grazing behavior-Thackeray Ranch

Horseback observations. The location of cows within the study pastures was recorded 2 times per week by observers on horseback, usually once in the morning and once in the afternoon. Pastures were divided into map units (1 to $6 \mathrm{ha}$ ), based on slope, aspect, elevation, and distance to water. The number of cows in each map unit was recorded during each observation. Average distance from supplement and water were calculated by measuring the distance from the map unit to supplement and water locations on scaled maps. In addition, the number of cows at supplement barrels $(<30 \mathrm{~m})$ was recorded.

GPS collars. Cattle were fitted with Lotek GPS 2000 collars (Lotek Engineering, Newmarket, Ontario) that record the location of cattle within 5 to 12 m (Moen et al. 1997). Seven to 12 collars were available to track cattle. At the beginning of the study, 4 randomly selected cows were fitted with collars that were powered with disposable batteries capable of recording and storing 3,000 locations. These 4 cows were tracked at 10-minute intervals for 10 days ( 7 days during period 1 and 3 days in period 2). At the end of period 1 , cattle were tracked with collars powered by rechargeable batteries capable of recording and storing 500 to 1,000 locations during mild to moderate temperatures. At cold temperatures (consistently $<-12^{\circ} \mathrm{C}$ ) collars with rechargeable batteries generally recorded and stored 150 to 300 locations. Because of the variation in collar performance, locations were sampled with several sampling schedules. Initial performance of the rechargeable batteries allowed sampling intervals to be changed to every 5 minutes during the day and every 10 minutes at night. Later as performance declined, the sampling interval was changed back to every 10 minutes. During the last 2 periods in late December and January, the schedule was changed to every 15 minutes during the day and every 30 minutes at night to extend battery life during cold weather.

A total of 81 randomly-selected cows were tracked during the study. Collars 


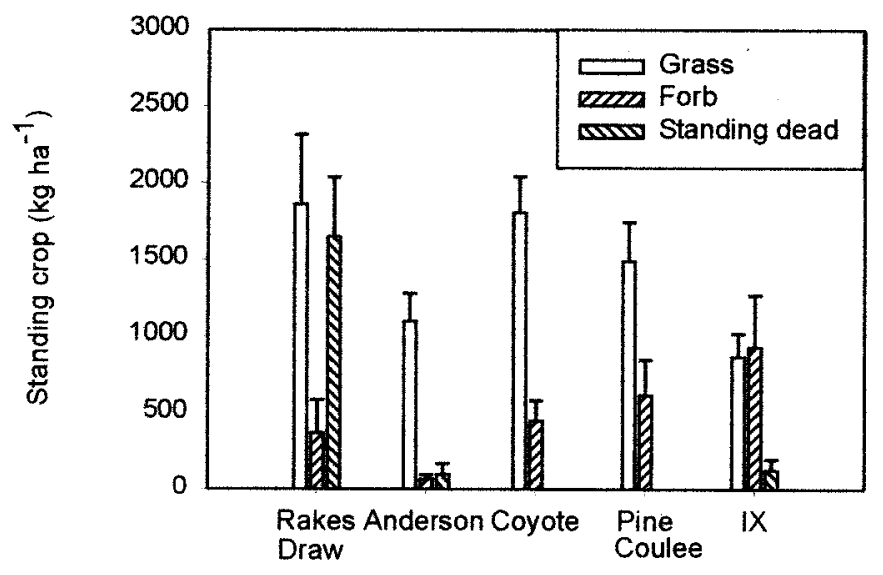

Fig. 4. Standing crop of current year's growth of grasses and forbs and previous years' vegetation (standing dead) at the Thackeray Ranch (Rakes Draw and Anderson pastures), Dana Ranch (Coyote and Pine Coulee sites) and IX Ranch. Standing dead vegetation could not be distinguished at the Dana Ranch and forage was pooled into grass and forbs.

were placed on sets of cows 9 different times. For each set of cows ( 7 to 12 animals), individual cow locations usually were recorded for 4 or 5 days. Then collars were removed, and the data were downloaded to a computer. Batteries were recharged, and collars were prepared and placed on another set of cows. These cycles from placement on 1 set of cows to placement on the next set took 7 to 9 days.

The location of supplement barrels were recorded with an 8-channel, L-Band GPS receiver with $\pm 1 \mathrm{~m}$ positional accuracy (Omnistar, Houston, Tex.). Locations of fence boundaries, gates, water and terrain features were also mapped with this GPS receiver.

\section{Statistical analyses}

Forage measurements-Thackeray and Dana Ranches. Changes in forage use and stubble height from the beginning to the end of a period (before supplement placement and after removal) were regressed on distance to supplement and slope (SAS 1985). Distance to water was not included in these analyses because it was highly correlated with distance to supplement. Changes in forage use also were regressed on distance to supplement alone. The 4 study sites (Anderson and Rakes Draw pastures and Coyote and Pine Coulee areas) were analyzed separately and included data from all periods.

Forage measurements-IX Ranch. Similar statistical procedures were used for the IX Ranch data except that distance to water was added to the multiple regression model. Changes in forage use and stubble height were regressed on distance distance to supplement. effect of supplement placement. Distance to supplement, distance to water and slope were used as independent variables. Separate simple regression models also were used to individually evaluate effects of distance to supplement, distance to water and slope on forage utilization. Distance to supplement in the final use analyses refers to distance to nearest supplement during any of the 3 periods.

Grazing behavior-Thackeray Ranch. Distances that cattle were observed from supplement (horseback and GPS data) were analyzed using chi-square procedures (Lehner 1979). The observed frequencies of cattle located at 200-m increments from supplement were compared to expected values using a goodness of fit test. Expected values were determined by multiplying the proportion of the pasture that each incremental distance comprised by the total number of cows observed at all distances from supplement. The size (ha) of each incremental distance from supplement was estimated using a planimeter within the geographical information system (ArcViewTM, ESRL, Redlands, Calif. Each cow location recorded by an observer was considered an observation. For the horseback observations, each pasture was analyzed separately. For GPS collar data, each cow during a period was considered an observa-

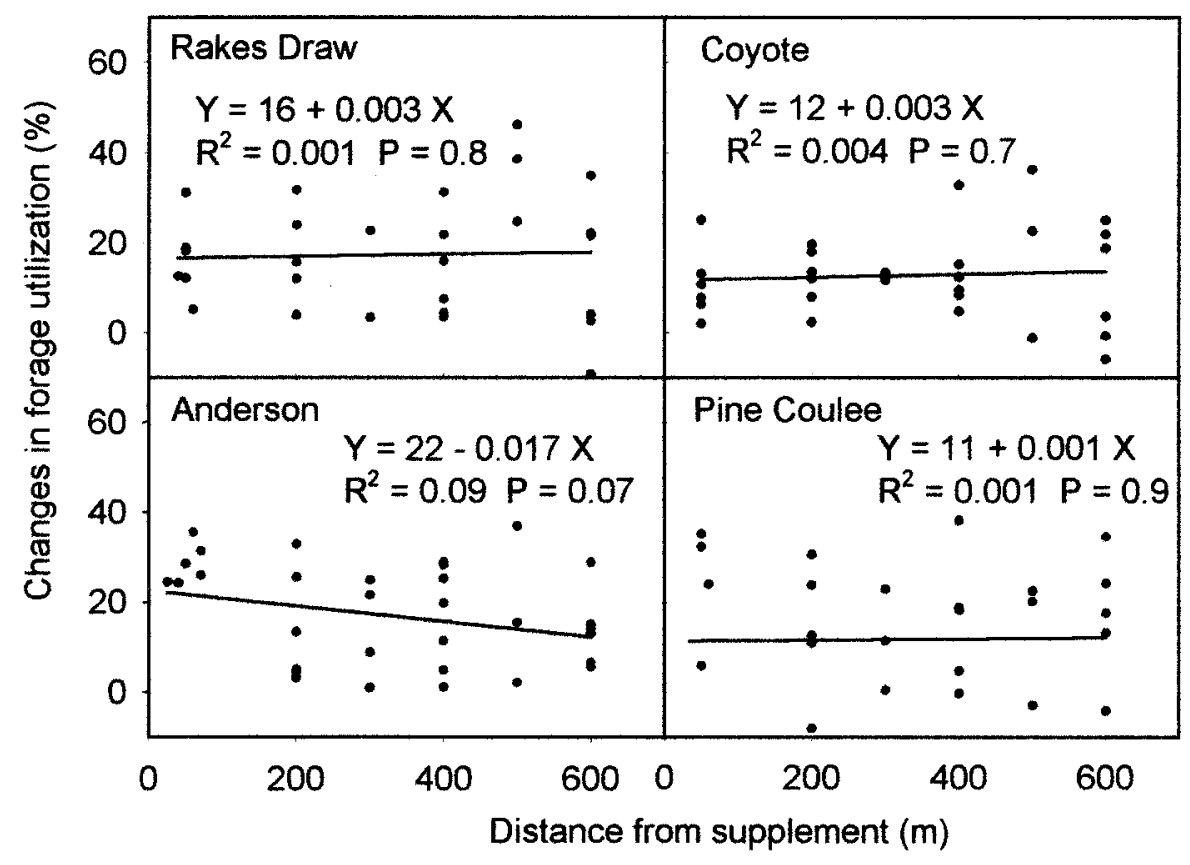

Fig. 5. Scatter plot of changes in forage utilization versus distance from supplement in the Rakes Draw and Anderson pastures at the Thackeray Ranch and Coyote and Pine Coulee study areas at the Dana Ranch. Changes in forage utilization were not related $(P>0.05)$ to 


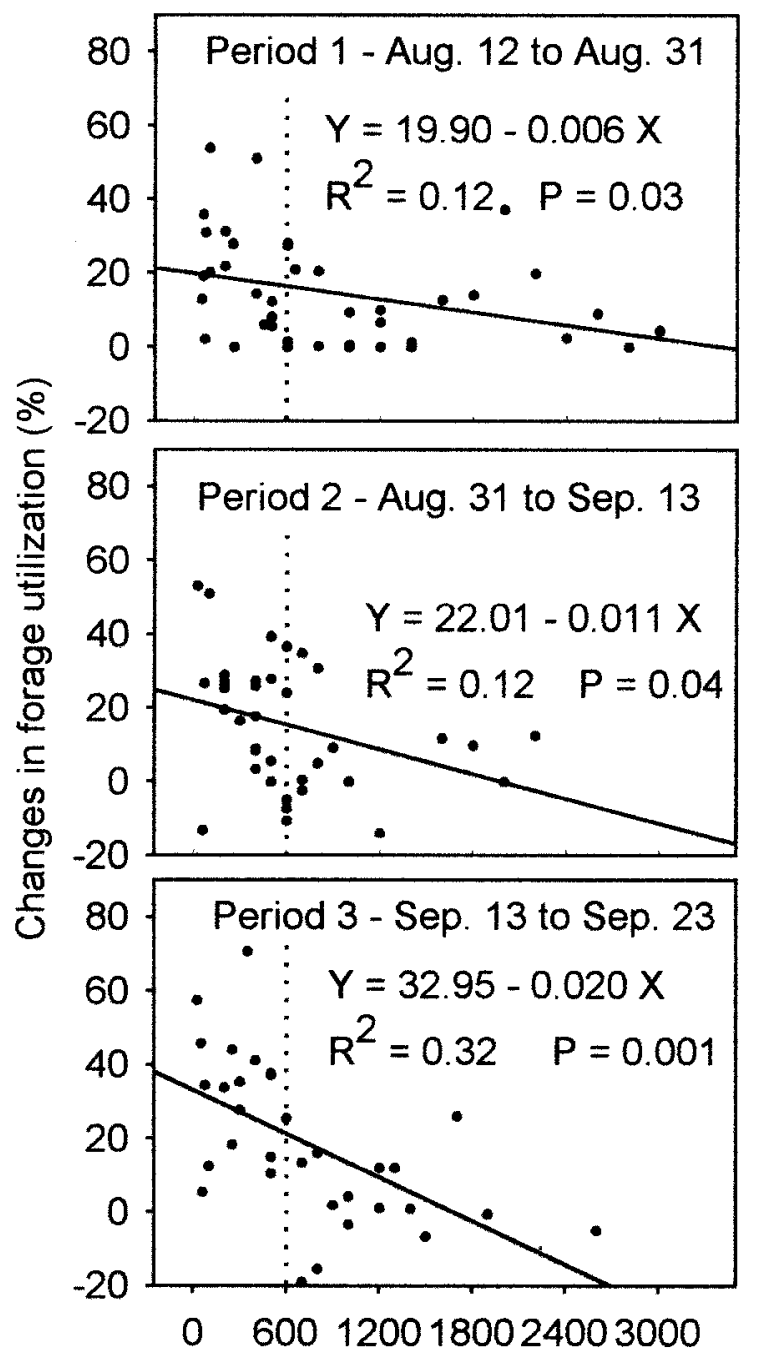

Distance to supplement $(\mathrm{m})$

Fig. 6. Scatter plot of changes in forage utilization and distance to supplement during periods 1,2 , and 3 at the IX Ranch. Changes in forage utilization were related $(P<0.05)$ to distance to supplement during all periods.

tion, and data for a cow during a period were averaged. Some cows $(n=24)$ were observed in 2 periods, and the data from each period was considered a separate observation. The rationale for considering them separate observations was that the supplement was placed in different locations during each period (Fig. 1).

\section{Results}

\section{Vegetation measurements}

Initial forage conditions. At the Thackeray Ranch, mean total standing crop (current year's growth of grass and forbs) in the Rakes Draw pasture was
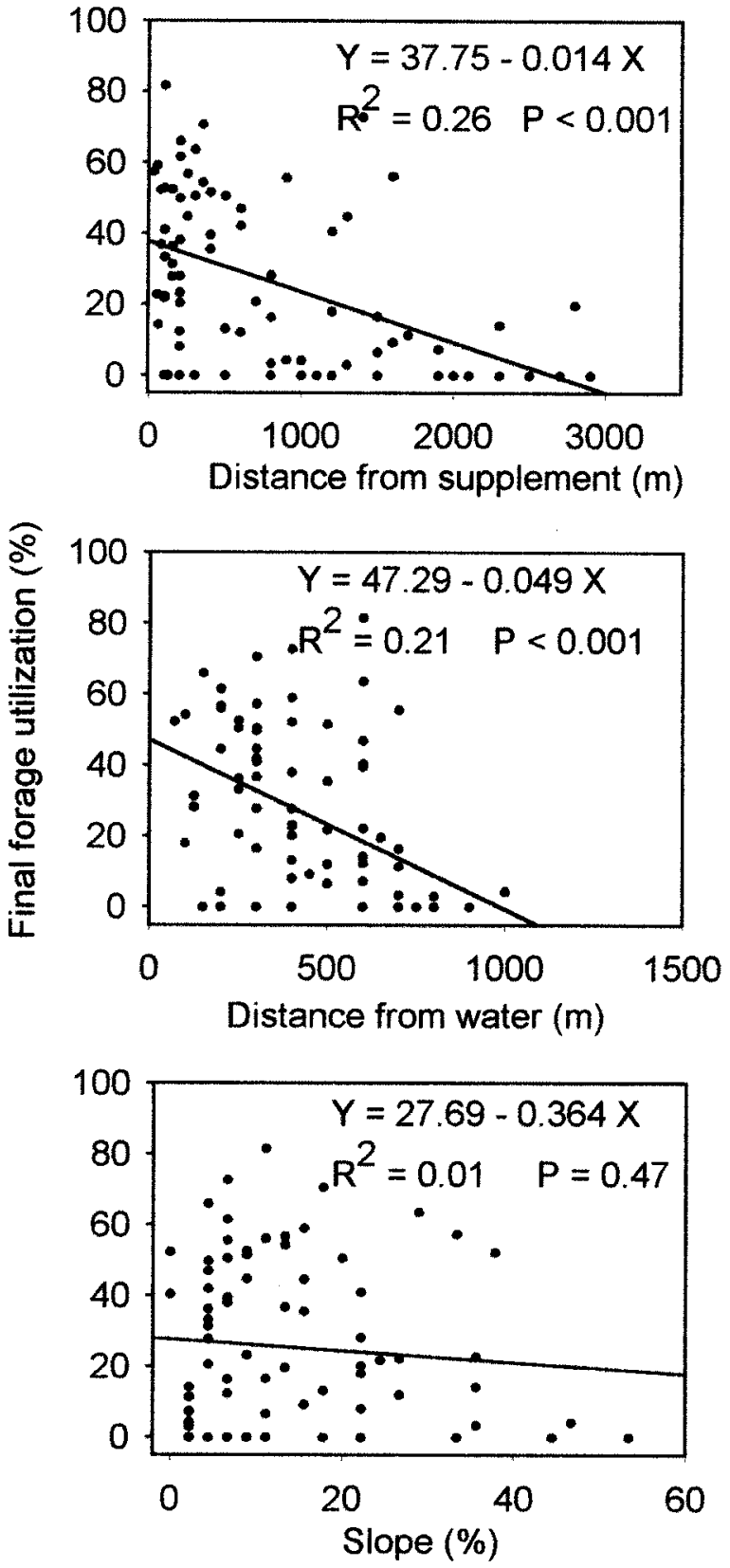

2,230 $\mathrm{kg} \mathrm{ha}^{-1}$ (Fig.

4). This pasture had not been grazed since July 1997 and contained a large quantity of previous years' vegetation (standing dead). The Anderson pasture had been grazed for 10 days in May 1998 and the total standing crop was about $1170 \mathrm{~kg}$ $\mathrm{ha}^{-1}$. Little standing dead vegetation was observed in the Anderson pasture. Mean standing crop at the Dana Ranch was 2,180 $\mathrm{kg} \mathrm{ha}^{-1}$. We were unable to distinguish standing dead at the Dana Ranch, and any standing dead vegetation was pooled into the grass and forb categories. At the IX Ranch, mean standing crop was $1,790 \mathrm{~kg}$ $\mathrm{ha}^{-1}$ with a large forb component and little standing dead vegetation.

Forage generally was dormant during autumn 1998 at the Thackeray and Dana Ranches and the nutritive value as measured by crude protein (CP) was consistently low. Crude protein concentration of grass at the Dana Ranch was $4.5 \%$ in the Coyote study area and $5.7 \%$ in the Pine Coulee study area at the beginning of the study (4 November 1998). At the end of the study (17 December 1998), forage CP concentration in the 2 study areas aver- 


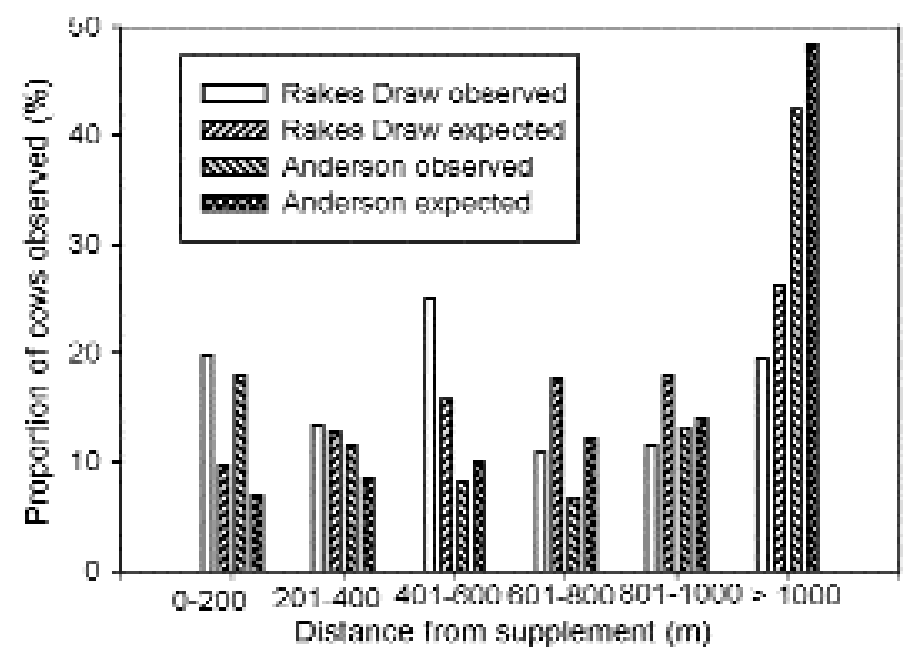

Fig. 8. Mean number of cattle at varying distances from supplement observed by horseback observers. Expected values reflect the proportion of the pasture that the incremental distance from supplement represents and the number of cattle observed. A total of 159 cattle grazed in both pastures. Grazing patterns differed from expected values $(P<0.05)$.

aged $4.1 \%$. In the Rakes Draw pasture during October 1998, mean CP concentration of the current year's grass growth was $6.5 \%$ and $4.4 \%$ for the bottoms and slopes, respectively. In the Anderson pasture during November 1998, mean CP concentration of the current year's grass was $5.4 \%$.

Forage utilization-Thackeray and Dana Ranches. In all study areas, changes in forage utilization and stubble height were similar $(\mathrm{P}>0.05)$ at all distances from 30 to $600 \mathrm{~m}$ (Fig. 5). Slope of terrain where vegetation was measured did not influence $(\mathrm{P}>0.1)$ change in forage use or stubble height. The mean increase in forage utilization was 14 percentage points during a period, but individual forage-utilization measurements varied by more than 20 percentage points at every distance measured in every study area (Fig. 5). Stubble heights decreased by an average of $20 \mathrm{~cm}$ within a period.

Forage utilization-IX Ranch. Using the multiple regression model, changes in forage utilization and stubble height were related $(\mathrm{P}<0.01)$ to distance from supplement ( 30 to $3,000 \mathrm{~m}$ ) during periods 2 and 3 , but in period 1 there was no relationship $(\mathrm{P}>0.1)$. Changes in forage utilization and stubble height were not related $(\mathrm{P}>$ $0.1)$ to distance to water and slope during any period. If distance to water and slope were removed from the model, changes in forage utilization decreased $(\mathrm{P}<0.01)$ as distance from supplement increased in all 3 periods (Fig. 6 )

Final forage utilization (end of period 3) decreased with distance to supplement ( $\mathrm{P}$ $<0.001)$, distance to water $(\mathrm{P}=0.02)$ and slope $(P=0.09)$ in the multiple regression analysis. Individual regressions of changes in forage utilization on distance to supplement, distance to water and slope (simple linear regression, Fig. 7), were similar to the multiple regression analyses except that the relationship between forage utilization and slope was no longer important $(\mathrm{P}=0.47)$.

\section{Cattle observations-horseback}

Observations near barrels. In the Rakes Draw pasture, the mean number of cows observed at the 8 supplement barrels was 12 , or 1.5 cows per barrel. In the Anderson pasture, the mean number of cows observed at barrels was 6 , or 0.75 cows per barrel. The number of cows observed at all 8 barrels ranged from 0 to 24 total animals or 0 to 3 cows per barrel in Rakes Draw. The range of cows at all 8 barrels in the Anderson pasture was 0 to 20 cows, or 0 to 2.5 cows per barrel. The number of cows observed at the barrels was similar $(\mathrm{P}>0.1)$ in the morning and afternoon.

Entire pasture observations. During the study, an average of $86 \%$ of the herd was observed. Cattle were not distributed uniformly ( $\mathrm{P}<0.001)$ across pastures (Fig. 8). In both the Rakes Draw and Anderson pastures, $18 \%$ of cows were within $200 \mathrm{~m}$ of supplement, and these areas made up $10 \%$ and $7 \%$ of the pasture acreage, respectively. In the Rakes Draw pasture, $58 \%$ of the cows were observed within $600 \mathrm{~m}$ of supplement ( $38 \%$ of the pasture). In the Anderson pasture, $38 \%$ of the cows were observed within $600 \mathrm{~m}$ of supplement ( $26 \%$ of the pasture).

\section{GPS collar observations}

Collared cows spent about $17 \%$ of their time within 200 yards of supplement in the Rakes Draws pasture and about $16 \%$ of their time in the Anderson pasture (Fig. 9). Cattle use of the areas between 0 to 200, 201 to 400,401 to 600 , and greater than $600 \mathrm{~m}$ from supplement was not different from what would be expected by chance (P > 0.05). Collared cows spent $40 \%$ and $33 \%$ of their time within $600 \mathrm{~m}$ of supplement in the Rakes Draw and Anderson pastures, respectively (Fig. 9).

\section{Discussion}

\section{Forage utilization}

Utilization levels. During the autumn and winter at the Thackeray and Dana Ranches, areas within 600 m of dehydrated molasses received grazing use by cattle even though the supplement sites were located on some of the steepest terrain and furthest areas from water. The mean increase in forage utilization in this study (14 percentage points) was similar to the 11 percentage point increase observed by Bailey and Welling (1999) in the same or similar pastures.

Forage utilization measurements show that cattle continued to forage in previously grazed areas as long as the areas remained within $600 \mathrm{~m}$ of supplement. In this study supplement was usually moved to an adjacent area 250 to $400 \mathrm{~m}$ from the first location (Fig. 1). Since change in forage utilization was consistent at all distances from supplement, forage utilization increased 20 to 30 percentage points during a month ( 2 periods) when supplement was nearby. So long as forage utilization is less than acceptable levels (40 to 55\%), placing supplement adjacent to undergrazed sites will likely encourage cattle to graze nearby.

Slope and distance to water. In contrast to other studies (Valentine 1947, Mueggler 1965, Cook 1966), slope and distance to water did not consistently affect forage utilization. Utilization measurements were not collected in areas where slopes exceeded $40 \%$. At the IX Ranch where distance to water was used as a variable, the pasture was well watered, and cattle had to travel less than $800 \mathrm{~m}$ to reach water in most of the pasture.

\section{Area affected by supplement}

For economic analyses of supplement placement on cattle grazing distribution, the extent of effects of supplement placement must be estimated. The relationships 


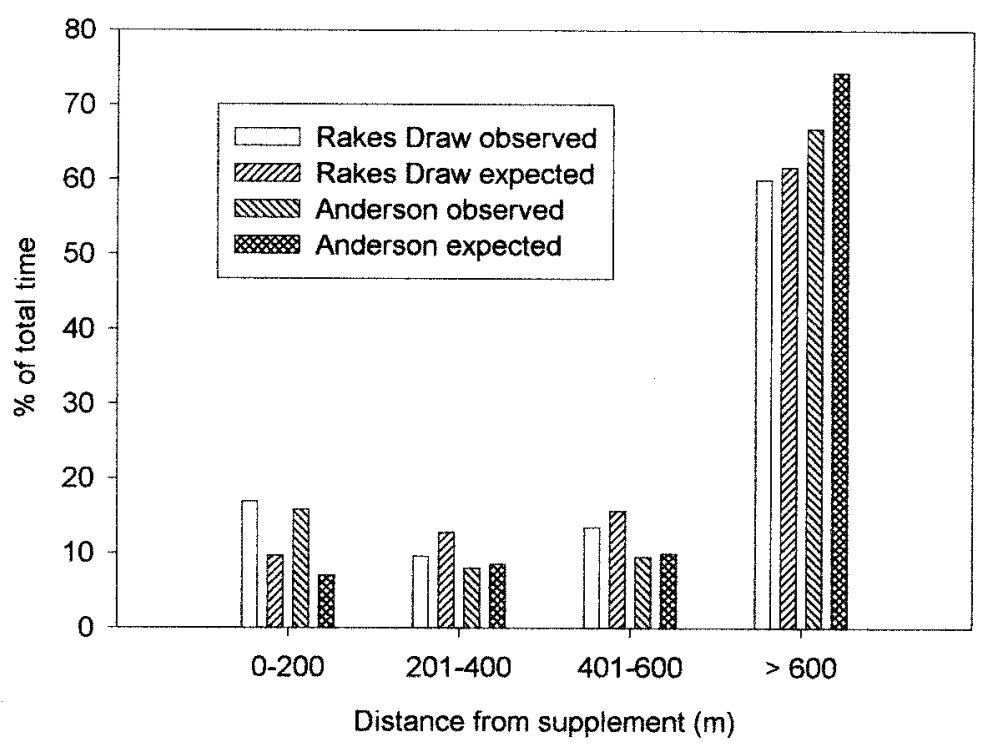

Fig. 9. Average use of terrain at varying distances from supplement by GPS collared cows in the Rakes Draw and Anderson pastures. Values are averages of individual collared cows $(n=81)$. Expected values reflect the proportion of the pasture that the incremental distance from supplement represents. Grazing patterns did not differ $(P>0.05)$ from expected values.

between changes in forage use and distance from supplement at all 3 locations (ranches) were used to estimate the distance to which 8 to 12 barrels (907 to $1,361 \mathrm{~kg}$ ) of supplement might affect cat-
Thackeray and Dana Ranches was relatively consistent for distances up to $600 \mathrm{~m}$. We expected a decline in forage use at 300 to $600 \mathrm{~m}$ from supplement. An additional study was conducted at the IX Ranch to estimate the furthest distance beyond which supplement would not affect cattle grazing patterns.

Unlike the results observed at Thackeray and Dana Ranches, forage use decreased linearly with increasing distance from supplement at the IX Ranch. Forage measurements were collected at distances greater than 2,000 $\mathrm{m}$ from supplement at the IX Ranch but at the other ranches measurements were not collected at distances greater than $600 \mathrm{~m}$ from supplement. When observations greater than $600 \mathrm{~m}$ from supplement were excluded from the analyses of IX Ranch data, the relationship between change in forage utilization and distance to supplement was not important (P > 0.1) for any period.

At the IX Ranch during period 1, the predicted change in forage utilization equaled the average measured change in forage utilization at $815 \mathrm{~m}$ from supplement. At distances greater than $815 \mathrm{~m}$ from supplement, the predicted change in forage use was less than the average observed. Thus, grazing distribution was not affected at distances of greater than $815 \mathrm{~m}$ from supplement during period 1 .

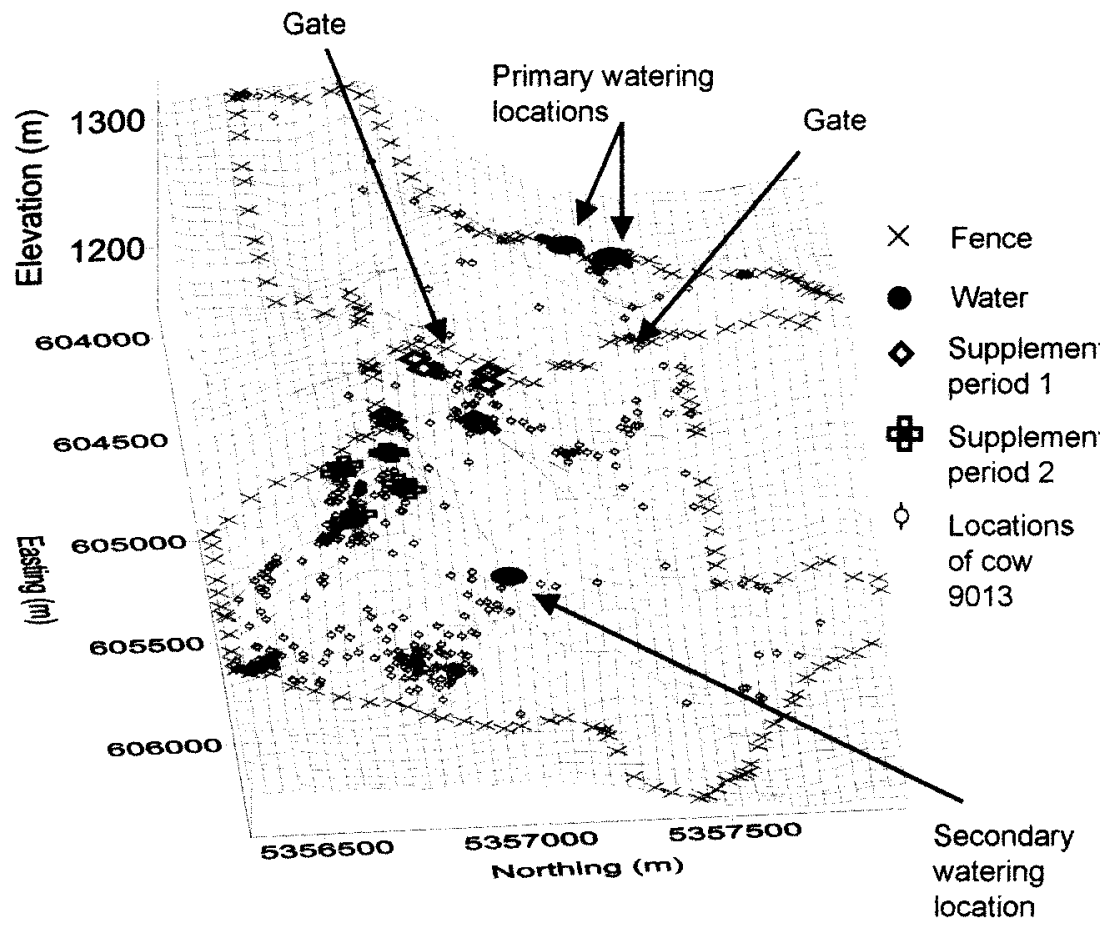

Fig. 10. Locations of cow 9013 the last 4 days of period 1 and the first 2 days of period 2 in the Rakes Draw pasture. Locations were recorded at 10 minute intervals using GPS collars. 
For period 2, the predicted change in forage utilization equaled the average measured change in forage utilization at $638 \mathrm{~m}$ from supplement. For period 3, predicted change in forage use equaled the average observed change in forage use at $725 \mathrm{~m}$ from supplement. During all 3 periods at the IX Ranch, cattle were not lured to areas further than 600 to $800 \mathrm{~m}$ from supplement. The consistency of the response to supplement from 30 to $600 \mathrm{~m}$ at the Thackeray and Dana Ranches and the estimated end of influence after $600 \mathrm{~m}$ at the IX Ranch suggests that the area that cattle were lured to graze by a single placement of supplement included areas up to $600 \mathrm{~m}$, but the effect of supplement on grazing patterns rapidly declined at distances greater than $600 \mathrm{~m}$ and ended before 800 $\mathrm{m}$ from supplement.

\section{Effective seasons of use}

Previous work with dehydrated molasses supplement to modify grazing distribution was conducted during the autumn and winter (Bailey and Welling 1999). Results from this study using nonlactating cows during the autumn and winter resulted in similar grazing patterns observed in the earlier study. At the IX Ranch, the decline in forage use at distances further from supplement demonstrated that dehydrated molasses supplement can effect grazing patterns of cowcalf pairs during August and September. Many concerns with livestock grazing in riparian and other areas occur during late summer (DelCurto et al. 1999).

\section{Cattle location}

Observations of cattle location corresponded well with vegetative measurements. Horseback observations showed that $18 \%$ of the cows were observed within $200 \mathrm{~m}$ of supplement and that cattle used areas further than $600 \mathrm{~m}$ from supplement less than expected by chance. Less than $20 \%$ of the cows were observed within $200 \mathrm{~m}$ of the primary water source. Data from GPS collars also showed that cattle distributed themselves relatively evenly from 0 to $600 \mathrm{~m}$ from supplement (e.g., Fig. 10). In the Bailey and Welling (1999) study about $30 \%$ of the cattle were observed in the areas (subunits) with supplement and only $3 \%$ were observed in control areas. Control areas were separated from areas with supplement in the Bailey and Welling (1999) study. In the Rakes Draw pasture, cattle utilized almost all of the difficult terrain near supplement, about $25 \%$ of the total area. Historically, this area of the pasture had received little grazing use by cattle.

At the IX Ranch, cattle historically used the western half of the pasture. Over $80 \%$ of the cattle were gathered from the western half of the pasture, and less than $20 \%$ were found on the eastern half (Steve Roth, personal communication). At the end of this study, the majority of the cattle (over 55\%) were gathered on the eastern half of the pasture. This anecdotal observation is consistent with the vegetative measurements that show that cattle grazed more near supplement placed in the eastern half of the pasture.

\section{Conclusions and Implications}

When dehydrated molasses supplement was placed in rugged foothills rangeland, cattle grazed nearby areas relatively evenly for distances of 0 to $600 \mathrm{~m}$ from supplement. If evaluated at distances greater than $600 \mathrm{~m}$, forage use declined linearly with increasing distances from supplement. Placement of 8 to 12 barrels (113 kg/barrel) of dehydrated molasses supplement affects cattle grazing patterns for distances up to $600 \mathrm{~m}$, but the influence rapidly declines beyond $600 \mathrm{~m}$. Supplement should not be expected to lure cattle to areas beyond 600 to $700 \mathrm{~m}$ from placement.

Placing dehydrated molasses supplement in undergrazed rangeland was an effective tool to modify cattle grazing distribution during late summer, autumn, and winter. Supplement should be placed in undergrazed rangeland within a limited area ( 5 to 15 ha in this study). When the supplement is consumed, new supplement should be placed in an adjoining undergrazed area. All cattle used to evaluate dehydrated molasses supplement in this study had been exposed to the supplement before the study began. Supplement may not be effective if cattle are not exposed to the supplement before it is placed in undergrazed rangeland.

\section{Literature Cited}

AOAC. 1990. Official methods of analysis (14th ed.) Association of Official Analytical Chemists. Washington, D.C

Bailey, D.W. and L.R. Rittenhouse. 1989. Management of cattle distribution. Rangelands 11:159-161.

Bailey, D.W. and G.R. Welling. 1999. Modification of cattle grazing distribution with dehydrated molasses supplement. J. Range Manage. 52:575-582.

Bailey, D.W., D.C. Anderson, and D.E. Doornbos. 1997. Comparison of ivermectin and conventional external parasite control in young beef cows. Prof. Anim. Sci. 13:129-132.
Bell, H.M. 1973. Rangeland management for livestock production. Univ. Oklahoma Press, Norman, Okla.

Cook, C. 1966. Factors affecting utilization of mountain slopes by cattle. J. Range Manage. 19:200-204.

Cook, C.W. and J. Stubbendieck. 1986. Range research: basic problems and techniques. Soc. Range Manage., Denver, Colo.

DelCurto, T., M. Porath, M. McInnis, P. Momont, and C. Parsons. 1999. Management strategies for optimal beef cattle distribution and use of mountain riparian meadows, $\mathrm{p}$. 119-129. In: K.L. Launchbaugh, K.D. Sanders and J.C. Mosley (eds.), Grazing behavior of livestock and wildlife. Idaho For., Wildlife and Range Exp. Sta. Bull. \# 70, Univ. of Idaho, Moscow, Ida.

Lehner, P.N. 1979. Handbook of ethological methods. Garland STPM Press, New York, N.Y.

Martin, S.C. and D.E. Ward. 1973. Salt and meal-salt help distribute cattle use on semidesert range. J. Range Manage. 26:94-97.

McDougald N.K., W.E. Frost and D.E. Jones. 1989. Use of supplemental feeding locations to manage cattle use on riparian areas of hardwood rangelands, p. 124-126. Proc. California Riparian Systems Conference, Davis, Calif., USDA For. Serv. Gen. Tech. Rep. PSW-110. Washington, D.C

Moen, R., J. Pastor and Y. Cohen. 1997. Accuracy of GPS telemetry collar locations with differential correction. J. Wildl. Manage. 61:530-539.

Mueggler, W.F. 1965. Cattle distribution on steep slopes. J. Range Manage. 18:255-257.

SAS. 1985. SAS user's guide: Statistics. SAS Inst., Inc. Cary, N.C.

U.S. Forest Service Rocky Mountain Forest and Range Experiment Station. 1980. Utilization gauge: an instrument for measuring the utilization of grasses. American Slide-Char Corp., Wheaton, Ill.

Valentine, K.A. 1947. Distance from water as a factor in grazing capacity of rangeland. J. Forest. 45:749-754. 